\title{
Soil gas radon-thoron monitoring in Dharamsala area of north-west Himalayas, India using solid state nuclear track detectors
}

\author{
Gulshan Kumar $^{1}$, Arvind Kumar ${ }^{2, *}$, Vivek Walia ${ }^{2}$, Jitender Kumar ${ }^{3}$, Vikash Gupta ${ }^{3}$, \\ Tsanyao Frank Yang ${ }^{4}$, Surinder Singh $^{5}$ and Bikramuit Singh Bajwa ${ }^{5}$ \\ ${ }^{1}$ Department of Physics, Govt. College Sarkaghat, Mandi 175 024, Himachal Pradesh, India. \\ ${ }^{2}$ National Center for Research on Earthquake Engineering, NARL, Taipei 106, Taiwan. \\ ${ }^{3}$ Arni School of Basic Sciences, Department of Physics, Arni University, Indora, Kangra, India. \\ ${ }^{4}$ Department of Geosciences, National Taiwan University, Taipei 106, Taiwan. \\ ${ }^{5}$ Department of Physics, Guru Nanak Dev University, Amritsar 143 005, India. \\ ${ }^{*}$ Corresponding author. e-mail: kumararvind79@hotmail.com
}

The study described here is based on the measurements of soil gas radon-thoron concentrations performed at Dharamsala region of north-west (NW) Himalayas, India. The study area is tectonically and environmentally significant and shows the features of ductile shear zone due to the presence of distinct thrust planes. Solid state nuclear track detectors (LR-115 films) have been used for the soil gas radon-thoron monitoring. Twenty five radon-thoron discriminators with LR-115 films were installed in the borehole of about $50 \mathrm{~cm}$ in the study areas. The recorded radon concentration varies from 1593 to $13570 \mathrm{~Bq} / \mathrm{m}^{3}$ with an average value of $5292 \mathrm{~Bq} / \mathrm{m}^{3}$. The recorded thoron concentration varies from 223 to $2920 \mathrm{~Bq} / \mathrm{m}^{3}$ with an average value of $901 \mathrm{~Bq} / \mathrm{m}^{3}$. The anomalous value of radon-thoron has been observed near to the faults like main boundary thrust (MBT and MBT2) as well as neotectonic lineaments in the region.

\section{Introduction}

Mapping faults and studying fault zone properties are important for seismic hazard analysis and for understanding earthquake physics. A fault is a fracture or zone of fractures that separates dfferent blocks of crust and accumulates a seismic strain subjected to large stress concentrations. When the energy associated with the accumulated strain is suddenly released, an earthquake occurs on the fault. During most earthquakes, fault motion stays below the earth's surface, but in large earthquakes, fault motion may break through to the surface, offsetting rocks and sediments, as well as anything built on the fault, as much as 10 feet or more.
Knowing the location of active faults is important so that planners and developers can avoid building houses or other structures, which would be destroyed when the fault breaks the earth's surface, on the faults. The variations of radon concentrations in the soil gas have been considered as a useful tool for earthquake monitoring and prediction in active fault zones (Liu et al. 1985; King 1986; Igarashi et al. 1995; Chyi et al. 2005; Yang et al. 2005, 2011; Kumar et al. 2009, 2012; Walia et al. 2009, 2013; Pereira et al. 2010; Singh et al. 2010) as well as for tracing neotectonic faults (Etiope and Lombardi 1995; Ciotoli et al. 1998; Guerra and Lombardi 2001; Fu et al. 2005; Walia et al. $2005,2010)$ because of radon noble geochemical 
characteristics. There exists quite a few other isotopes of radon besides ${ }^{222} \mathrm{Rn}$; the most notable ones are ${ }^{220} \mathrm{Rn}$ that is known as thoron and ${ }^{219} \mathrm{Rn}$, which is known as actinon.

Radon is a short-lived decay product derived from the ${ }^{238} \mathrm{U}$ decay series, with a half-life of 3.8 days. Thoron is a decay product derived from the ${ }^{232}$ Th decay series and has a relatively short half-life $(55 \mathrm{~s})$ that makes it useful in discriminating sectors with very fast soil-gas transport and/or Th-rich mineral outcrops. Actinon is part of the decay series of ${ }^{235} \mathrm{U}$ and has such a short half-life $(4 \mathrm{~s})$ that is neglected in geochemical exploration. However, only a few studies have mentioned thoron $\left({ }^{220} \mathrm{Rn}\right)$ for the same applications due to its short half-life (LaBrecque 2002; Yang et al. 2005).

For radon-thoron monitoring, various techniques (active as well as passive) have been reported in literature (Eappen and Mayya 2004; Papastefanou 2007; Pereira et al. 2010; Kumar et al. 2013). Walia et al. (2008) have studied soil-gas activity in the vicinity of neotectonic fault zones within the Dharamsala area in the region of the north-west Himalayas, India, by determining enhanced concentration values of radon and helium in the soil, using active detectors, viz., ionization chamber and ASM 100 HDS (Alcatel). However, these instruments available in the market are cost prohibitive. Application of solid state nuclear track detectors (SSNTDs) for radon-thoron measurements is widely accepted (Beck and Gingrich 1976; Gingrich and Fisher 1976) since these detectors are affordable and have the advantage to withstand parametric changes in the atmosphere when deployed in open environments (Tommasino 1990). Various types of SSNTDs are used in different exposure modes for the measurement of radon. Dosimeters of specific designs have been developed using SSNTDs (Eappen and Mayya 2004; Al-Azmi 2009).

In the present study, passive detectors (LR-115 films) has been used in radon-thoron discriminator for the measurement of soil gas radon-thoron in the Dharamsala region of NW Himalayas, India to check the effectiveness of this low cost technique and to know the variations of soil gas radon-thoron concentrations in the tectonically and environmentally significant area.

\section{Geology and tectonic setting of the study area}

The high seismicity and associated geological phenomena along the Himalayan belt are related to the collision of the Indian and Eurasian converging plates. As a result of this, a series of major thrust planes, the main central thrust (MCT), the main boundary thrust (MBT) and the Himalayan frontal thrust (HFT), have been formed (Gansser 1964). Dharamsala area $\left(32^{\circ} 13^{\prime} \mathrm{N}, 76^{\circ} 19^{\prime} \mathrm{E}, 52\right.$ D/SW) of the NW Himalayas lies on the southern slope of the Dhauladhar range (figure 1). The geology of the Dharamsala area which forms a part of lesser and outer Himalayas is characterized by the occurrence of the following formations/group (figure 2) from north to south, viz., Dhauladhar granite, Chail formation, Dharamsala traps, Dharamkot limestone, Sabathus, Dharamsala group and Shivalik group. Diverse lithology (Mahajan et al. 1997) within a short span of distance makes the study area tectonically and environmentally significant and shows the features of ductile shear zone due to the presence of distinct thrust planes. From south to north, these are MBT-2 (locally known as Drini Thrust), MBT and MCT (locally known as Chail Thrust). The individual formations and groups are separated from one another by longitudinal thrust systems (Mahajan and Virdi 2000) and the area is cross-cut by transverse faults/lineaments trending northeast-southwest. Kumar and Mahajan (2001) have correlated the Kangra earthquake (1905) and the Dharamsala earthquake (1986) with MBT and its subsidiary Drini thrust in the northeast to southwest direction while the Dharamsala earthquake (1978) is correlated with a transverse fault.

\section{Methodology}

Radon-thoron discriminator using SSNTDs has been used for the measurement of radonthoron concentrations in Dharamsala areas of NW Himalayas, India. Radon-thoron discriminator consists of a polyvinyl chloride (PVC) plastic tube of $6 \mathrm{~cm}$ diameter and $25 \mathrm{~cm}$ length with the top closed. A small rectangular attachment of aluminum (film holder) can be slipped into it. The rectangular attachment has two grooves where SSNTDs can be fixed. The detector consists of 100 $\mu \mathrm{m}$ thick transparent supporting plastic foil with a layer of $12 \mu \mathrm{m}$ thick red coloured cellulose nitrate (LR-115 type $\Pi$ ) which is sensitive to alpha radiation. The upper detector records tracks due to radon alone while lower detector records tracks due to radon and thoron. At the bottom of discriminator, a filter was placed to avoid the contribution from progeny concentrations. Twenty five discriminators along with LR-115 films were kept in the auger hole (about $50 \mathrm{~cm}$ depth) for two weeks during dry period, i.e., May-June 2012. After retrieval, the detector films were etched in $2.5 \mathrm{~N} \mathrm{NaOH}$ solution at a constant temperature of $60^{\circ} \mathrm{C}$ for $60-90$ minutes using the etching bath. For the calculation of track density, optical microscope has been used to scan the chemically etched tracks in the 


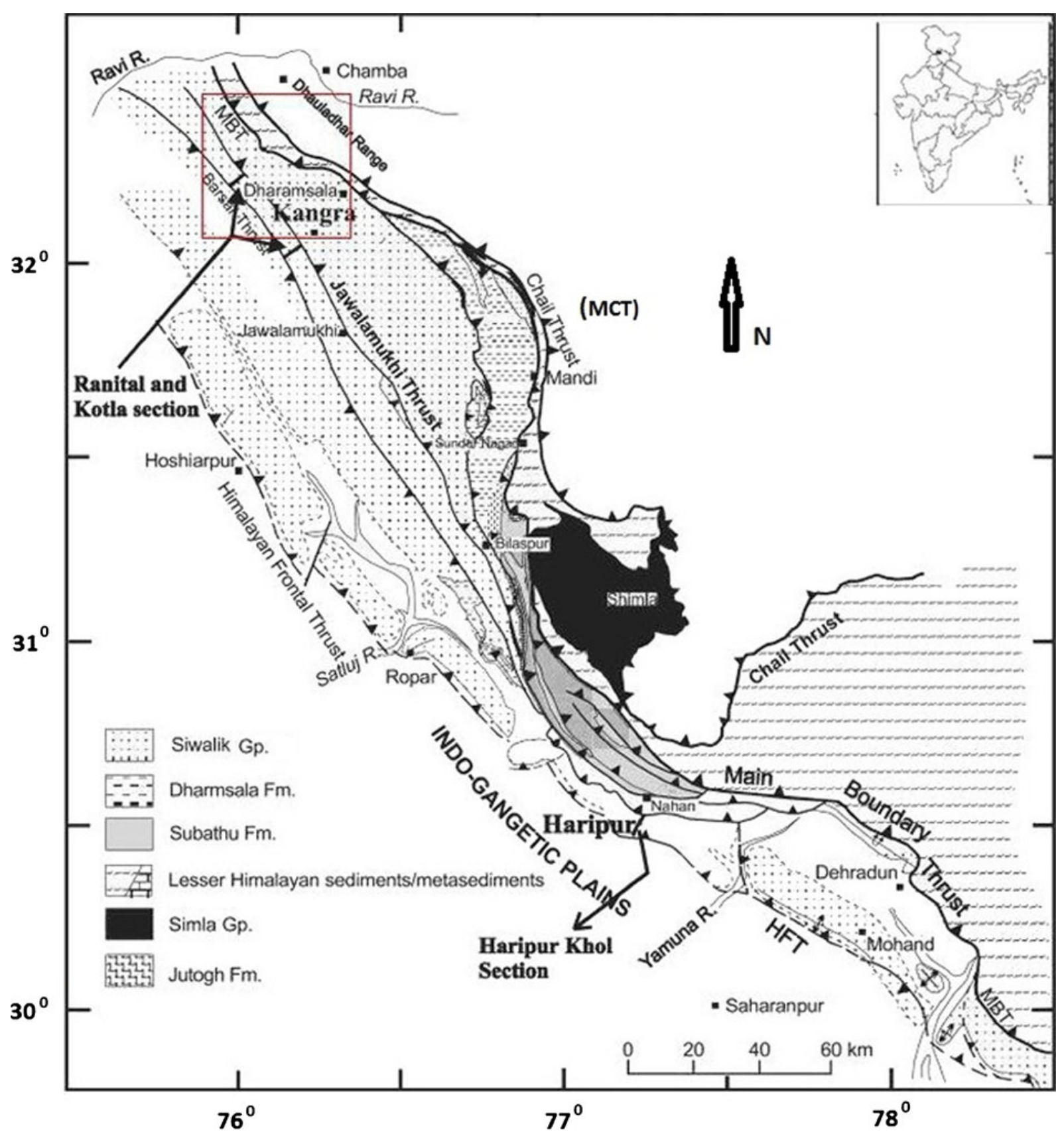

Figure 1. Geological map showing the location of study area.

samples. The measured track density for radon and thoron has converted into $\mathrm{Bq} / \mathrm{m}^{3}$ using the calibration factor described elsewhere (Eappen and Mayya 2004).

\section{Results and discussions}

Figure 2 shows the 25 sampling locations where LR-115 films have been installed inside radonthoron discriminators in the Dharamsala area of NW Himalayas. The results of soil gas concentration variations of radon and thoron are shown in table 1 . The recorded radon concentration varies from 1593 to $13570 \mathrm{~Bq} / \mathrm{m}^{3}$ with an average value of $5292 \mathrm{~Bq} / \mathrm{m}^{3}$ whereas recorded thoron concentration varies from 23 to $2920 \mathrm{~Bq} / \mathrm{m}^{3}$ with an average value of $901 \mathrm{~Bq} / \mathrm{m}^{3}$. In the present study, radon has shown higher values than of thoron due to short half-life of thoron, it cannot be detected from the greater depth. Further, the effect of moisture on the film at the lower part of discriminator due to its close proximity to the surface, can also be considered as one of the factors in suppressing the thoron signals. The recorded average radon value in the present study is closer to the 


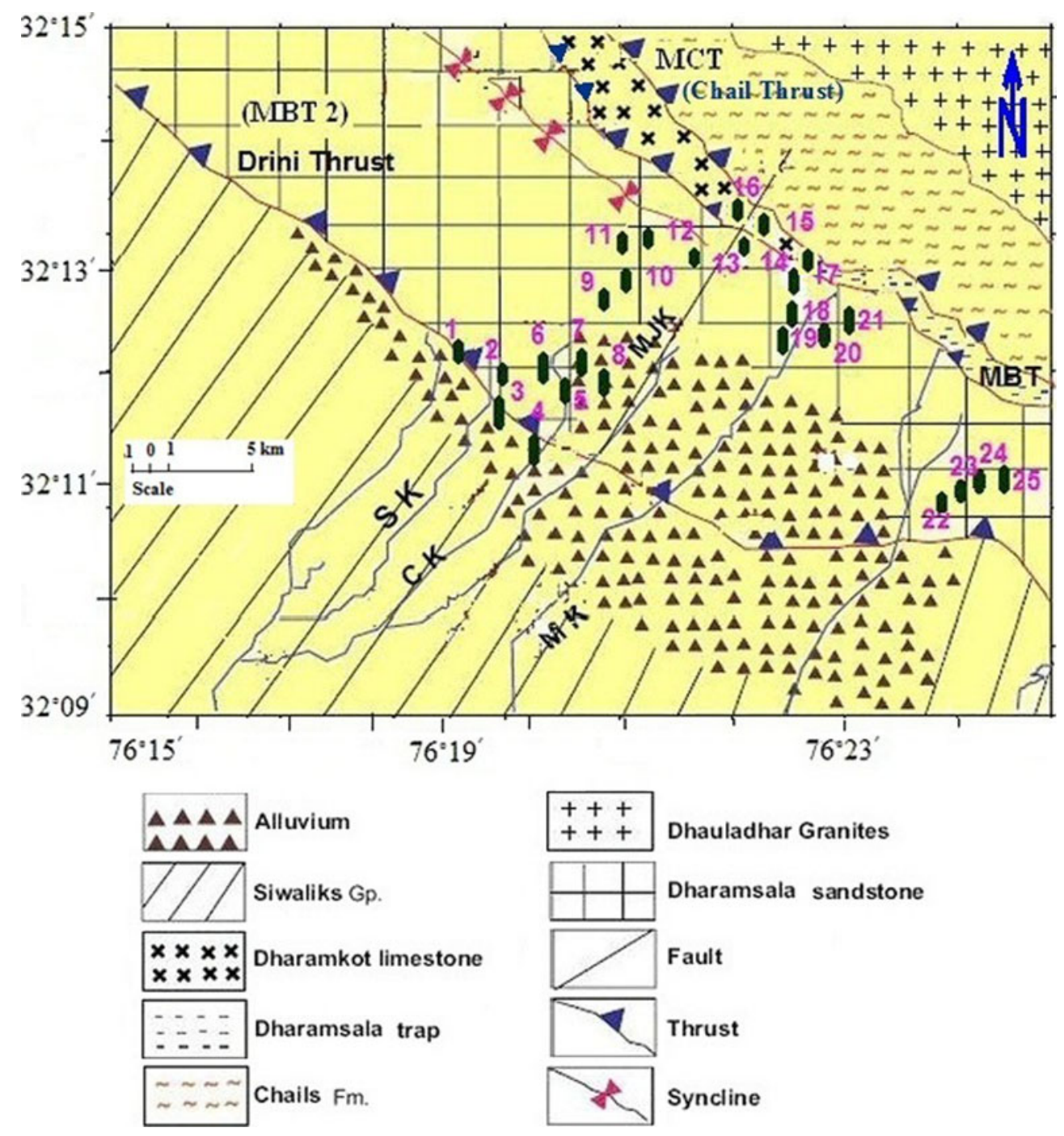

Figure 2. Geological map showing the locations of radon-thoron discriminators installed in the study area and tectonic features (MBT = Main Boundary Thrust, MCT = Main Central Thrust) and drainage systems (SK = Sarah Khad, CK = Churan Khad, MJK = Manjhi Khad, MK = Manuni Khad, DK = Darun Khad) (modified after Mahajan et al. 1997).

average values of the radon reported in the Nurpur area of NW Himalayas using SSNTDs (Singh et al. 2006) whereas it is less than the average value reported in the Nurpur (Mahajan et al. 2010) and the Dharamsala area (Walia et al. 2008) of NW Himalayas using active detectors. The difference in the average radon value in the present study with Mahajan et al. (2010) and Walia et al. (2008) may be due to the different techniques used for radon monitoring.

In order to identify possible threshold values of anomalous soil radon-thoron concentrations, various statistical methods have been used by different authors in the past (Guerra and Lombardi 2001; $\mathrm{Fu}$ et al. 2005; Walia et al. 2005; Pereira et al. 2010). In our context, statistical threshold values of radon-thoron gas anomalies are fixed at mean plus one standard deviation and anomalously high values were neglected, which may cause unnecessary high deviation and perturb the real anomalies. Figure 3 shows the high anomalous value of radon-thoron in the study areas. The primary vertical axis in the figure represents radon values and the secondary vertical axis represent thoron values at each sampling location whereas the line drawn (i.e., for $\mathrm{X}+1 \sigma$ ) in the figure is for both radon and thoron. The value of radon concentration was found to be anomalous at sampling points $2,3,12$, $14,20,21$ and 22 whereas the value of thoron concentration was found to be anomalous at sampling points $3,8,12,17,20$ and 21, respectively. At sampling points 14 and 22, the recorded radon concentrations found to be anomalous whereas thoron concentrations were not. This may be due to the deeper source of gas in the study area as reported by Yang et al. (2005). Also at sampling points 8 and 
Table 1. Recorded radon-thoron concentration in the Dharamsala area of NW Himalayas, India.

\begin{tabular}{|c|c|c|}
\hline Sl. no. & $\begin{array}{c}\mathrm{Rn} \\
\left(\mathrm{Bq} / \mathrm{m}^{3}\right)\end{array}$ & $\begin{array}{c}\mathrm{Th} \\
\left(\mathrm{Bq} / \mathrm{m}^{3}\right)\end{array}$ \\
\hline 1 & 5757 & 727 \\
\hline 2 & 6583 & 1243 \\
\hline 3 & 13570 & 1320 \\
\hline 4 & 3150 & 963 \\
\hline 5 & 2260 & 290 \\
\hline 6 & 2557 & 250 \\
\hline 7 & 5117 & 507 \\
\hline 8 & 6387 & 1320 \\
\hline 9 & 1743 & 593 \\
\hline 10 & 3747 & 464 \\
\hline 11 & 5507 & 527 \\
\hline 12 & 12827 & 2920 \\
\hline 13 & 5080 & 897 \\
\hline 14 & 6887 & 1223 \\
\hline 15 & 2380 & 643 \\
\hline 16 & 1873 & 223 \\
\hline 17 & 6003 & 1307 \\
\hline 18 & 5700 & 710 \\
\hline 19 & 5553 & 660 \\
\hline 20 & 8187 & 1704 \\
\hline 21 & 9000 & 1817 \\
\hline 22 & 6597 & 997 \\
\hline 23 & 2000 & 244 \\
\hline 24 & 2263 & 723 \\
\hline 25 & 1593 & 253 \\
\hline Average & 5292.84 & 901 \\
\hline
\end{tabular}

17 , the recorded values of thoron were anomalous where as radon concentrations were not. It may be due to the shallower gas source in the study area (Yang et al. 2005). This gas source can only provide a small amount of radon/thoron gas to the surface due to the microfracture and this small amount of gas may not increase the radon concentration clearly due to its original relative high background level. In contrast, it will significantly enhance the thoron concentration.

At sampling points $3,12,20$ and 21 , both radon and thoron values were found to be anomalous. The sampling point 3 , where the recorded values for both radon and thoron were anomalous lying on the Drini thrust (MBT2). The sampling point 14 where the recorded values for radon was anomalous and sampling point 17 where the recorded values for thoron was anomalous, this may be attributed to the presence of MBT nearby or due to probable lineaments which are common features along different drainage systems in the study area as reported by earlier studies (Dhar et al. 2002; Walia et al. 2008). The sampling point 12 where both radon-thoron values were anomalous lying very close to Syncline. The points 20 and 21, where the recorded values for radon-thoron were anomalous lying very close to Manuni Khud lineament. At sampling point 8 where the recorded thoron value was anomalous lying in between Churan Khad and Manjhi Khad. The low value for radon and thoron has been recorded at sampling points 15 and 16

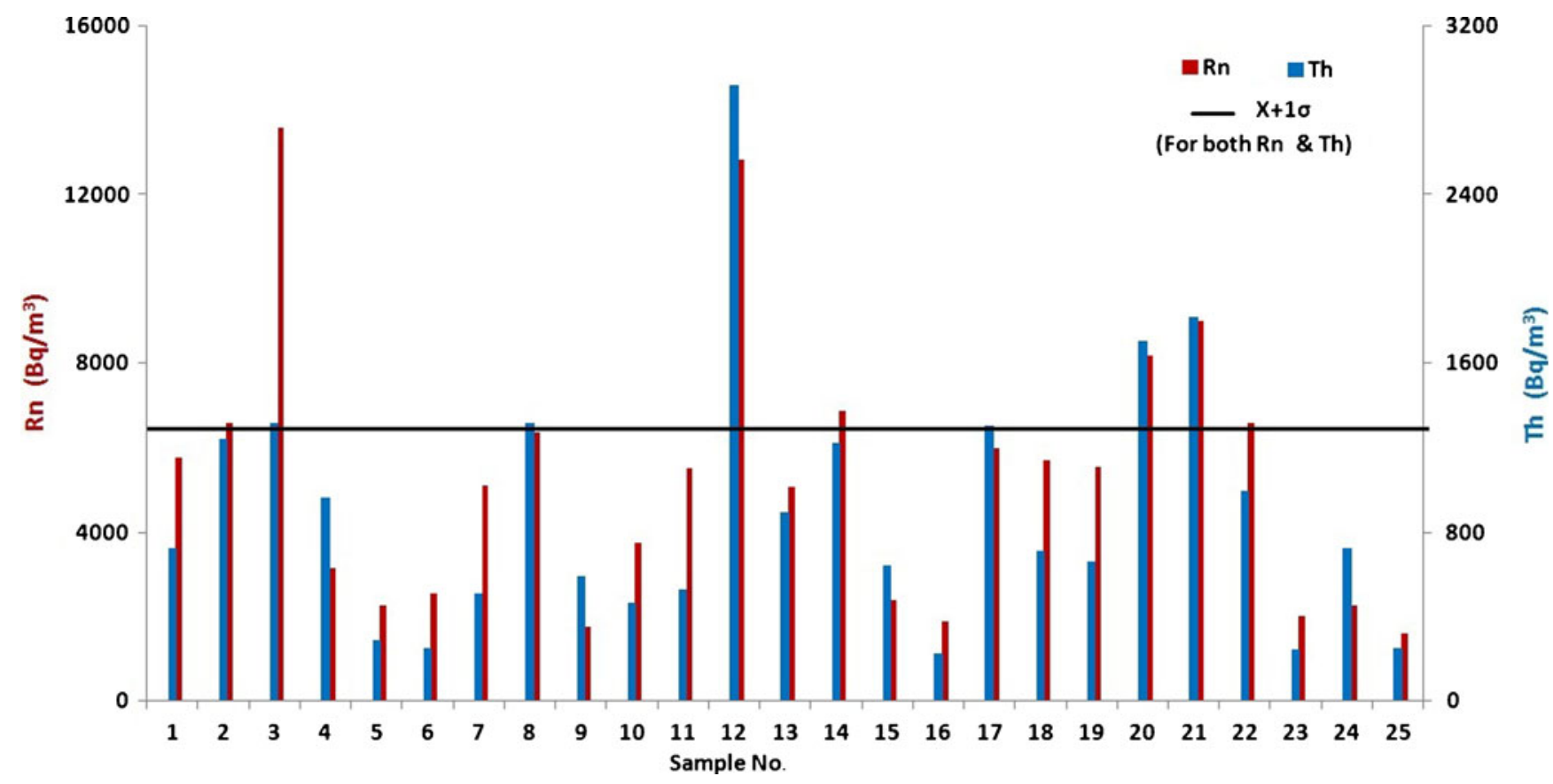

Figure 3. Radon-thoron data as small bar-charts over each location point. 
located in fault junction. The possible reason for low values for radon and thoron is that these two points are in the ductile zone in between MBT and MCT, may be having higher porosity, but low permeability. The sampling points $1,2,3$ and 4 are located around the MBT2. However, only two sampling points, i.e., 2 and 3 have identified anomalous values of radon/thoron. Although, the points 1 and 4 have not shown anomalous values, the value of radon at point 1 and value of thoron at point 4 are found to be higher than the average value, respectively. Overall the anomalous values of radon and thoron were found near to the faults, i.e., main boundary thrust (MBT and MBT2) as well as near Churan Khad (CK), Manuni Khad (MK) and Manji Khad (MJK). These anomalies indicate the presence of lineaments controlling this drainage system. Dhar et al. (2002) have already observed intersection pattern of longitudinal thrust and transverse lineaments along Manji Khad (MJK) in the area of Dharamsala.

Walia et al. (2008) have also studied soil-gas activity in the vicinity of neotectonic fault zones within the Dharamsala area in the region of the NW Himalayas, India, using active detectors. The authors have also reported anomalous value of radon near to the neotectonic thrust in the regions like main boundary thrust (MBT2) and also along the drainage system in the study area. The similar work is also in progress for soil gas radonthoron monitoring using SSNTDs in other seismically active zones of NW Himalayas, India and will be reported in the future.

\section{Conclusions}

An economical and simple method has been evolved to measure soil gas radon-thoron simultaneously using discriminator deploying LR-115 films. In Dharamsala areas, recorded soil gas radon concentration varies from 1593 to $13570 \mathrm{~Bq} / \mathrm{m}^{3}$ with an average value of $5292 \mathrm{~Bq} / \mathrm{m}^{3}$ whereas recorded soil gas thoron concentration varies from 223 to $2920 \mathrm{~Bq} / \mathrm{m}^{3}$ with an average value of $901 \mathrm{~Bq} / \mathrm{m}^{3}$. The anomalous value of radon-thoron has been observed near to the faults in the region, i.e., main boundary thrust (MBT, MBT2) and also along the drainage system in the study area. The presence of neotectonic faults/lineaments in the region has made it tectonically active. Based on the preliminary results of the present study and from the previous studies, it is suggested that the detailed studies of radon-thoron along with other noble gases will be fruitful for such kind of studies.

\section{Acknowledgements}

The authors are thankful to National Science Council of Taiwan and Department of Science and Technology for supporting this work financially under the project (NSC 100-2116-M-492002). Thanks are also due to the administration and staff of the Arni University, Indora and Guru Nanak Dev University, Amritsar for their valuable cooperation to complete this work. The authors are grateful to the anonymous reviewer for the valuable comments that improved the manuscript.

\section{References}

Al-Azmi D 2009 The use of soil gas as radon source in radon chambers; Radiat. Meas. 44 306-310.

Beck L S and Gingrich J E 1976 Track etch orientation survey in the Cliff Lake area, Northern Saskatchewan; Canadian Inst. Min. and Met. Bull. 69 104-109.

Ciotoli G, Guerra M, Lombardi E and Vittori E 1998 Soil gas survey for tracing seismogenic faults: A case study in the Fucino basin, central Italy; J. Geophys. Res. 103 23781-23794.

Chyi L L, Quick T J, Yang T F and Chen C H 2005 Soil gas spectra and earthquakes; Terr. Atmos. Ocean. Sci. (TAO) 16 763-774.

Dhar S, Singh S, Dogra M and Kochhar N 2002 Geological significance of radon in eco-system of Dharamsala area, Himachal Pradesh, India; Nat. Hazards Mitig. (Spec. Bull. IGA, PU, Chandigarh) 35(2) 139-147.

Eappen K P and Mayya Y S 2004 Calibration factors for LR-115 (type-II) based radon thoron discriminating dosimeter; Radiat. Meas. 38 5-17.

Etiope G and Lombardi S 1995 Evidence for radon transport by carrier gas through faulted clays in Italy; J. Radioanal. Nucl. Chem. 193 291-300.

Fu C C, Yang T F, Walia V and Chen C H 2005 Reconnaissance of soil gas composition over the buried fault and fracture zone in southern Taiwan; Geochem. J. 39 427-439.

Gansser A 1964 Geology of Himalayas; Interscience, New York.

Gingrich J E and Fisher J C 1976 Uranium exploration using the Track-Etch method; In: Exploration for Uranium Ore Deposits; IAEA, Vienna, pp. 213-227.

Guerra M and Lombardi S 2001 Soil-gas method for tracing neotectonic faults in clay basins: The Pisticci field (Southern Italy); Tectonophys. 339 511-522.

Igarashi G, Saeki S, Takahata N, Sumikawa K, Tasaka S, Sasaki Y, Takahashi M and Sano Y 1995 Groundwater radon anomaly before the Kobe earthquake in Japan; Science 269 60-61.

King C Y 1986 Gas geochemistry applied to earthquake prediction: A review; J. Geophys. Res. 91 12,269-12,281.

Kumar S and Mahajan A K 2001 Seismotectonics of the Kangra region north Himalaya; Tectonophys. 331(4) 359-371.

Kumar A, Singh S, Mahajan S, Bajwa B S, Kalia R and Dhar S 2009 Earthquake precursory studies in Kangra valley of north-west Himalayas, India, with special emphasis on radon emission; Appl. Radiat. \& Isot. 67 1904-1911.

Kumar A, Walia V, Singh S, Bajwa B S, Mahajan S, Dhar S and Yang T F 2012 Earthquake precursory 
studies at Amritsar Punjab, India using radon measurement techniques; Int. J. Phys. Sci. 7(42) 5669-5677.

Kumar A, Walia V, Yang T F, Hsien C H, Lin S J, Eappen K P and Arora B R 2013 Radon-thoron monitoring in Tatun volcanic areas of northern Taiwan using LR115 alpha track detector technique: Precalibration and Installation; Acta Geophysica (in press).

LaBrecque J J 2002 Simple and rapid methods for onsite determination of radon and thoron in soil-gases for seismic studies; J. Radioanal. Nucl. Chem. 254 439-444.

Liu K K, Yui T F, Yeh Y H, Tsai Y B and Teng T 1985 Variations of radon content in ground waters and possible correlation with seismic activities in northern Taiwan; Pure Appl. Geophys. 122 231-244.

Mahajan A K and Virdi N S 2000 Preparation of landslides hazard zonation map of Dharamsala town and adjoining areas, District Kangra (H.P.); Project report, H.P. Government, 45p.

Mahajan A K, Kumar S and Chabak S K 1997 Local gravity anomaly and geotectonics in the Dharamsala and Palampur area, north-west Himalayas; J. Geol. Soc. India $\mathbf{5 0}$ 75-84.

Mahajan S, Walia V, Bajwa B S, Kumar A, Singh S, Seth N, Dhar S, Gill G S and Yang T F 2010 Soil-gas radon/helium surveys in some neotectonic areas of NW Himalayan foothills, India; Nat. Hazards Earth Syst. Sci. 10 1221-1227.

Papastefanou C 2007 Measuring radon in soil gas and groundwaters: A review; Ann. Geophys. 50 569-578.

Pereira A J S C, Godinho M M and Neves L J P F 2010 On the influence of faulting on small-scale soil-gas radon variability: A case study in the Iberian Uranium Province; J. Environ. Radioac. $101875-882$.

Singh S, Sharma D K, Dhar S and Randhawa S S 2006 Geological significance of soil gas radon: A case study of Nurpur area, district Kangra, Himachal Pradesh, India; Radiat. Meas. 41(4) 482-485.

Singh S, Kumar A, Bajwa B S, Mahajan S, Kumar V and Dhar S 2010 Radon monitoring in soil gas and ground water for earthquake prediction study in NW Himalaya, India; Terr. Atmos. Ocean Sci. 21(4) 685-695.

Tommasino L 1990 Radon monitoring by alpha track detection; In: Proc. Int Workshop on Radon Monitoring in Radioprotection, Environmental Radioactivity and Earth Science (eds) Tommasino et al., Trieste, 1981, World Scientific, Singapore, pp. 123-132.

Walia V, Su T C, Fu C C and Yang T F 2005 Spatial variations of radon and helium concentrations in soil gas across the Shan-Chiao fault, northern Taiwan; Radiat. Meas. 40 $513-516$.

Walia V, Mahajan S, Kumar A, Singh S, Bajwa B S, Dhar S and Yang T F 2008 Fault delineation study using soilgas method in Dharamsala area, NW Himalayas, India; Radiat. Meas. 43 S337-S342.

Walia V, Yang T F, Lin S J, Hong W L, Fu C C, Wen K L and Chen C H 2009 Continuous temporal soil-gas composition variations for earthquake precursory studies along Hsincheng and Hsinhua faults in Taiwan; Radiat. Meas. 44 934-939.

Walia V, Lin S J, Fu C C, Yang T F, Hong W L, Wen K L and Chen C H 2010 Soil-gas monitoring: A tool for fault delineation studies along Hsinhua Fault (Tainan), southern Taiwan; Appl. Geochem. 25 602-607.

Walia V, Yang T F, Lin S J, Kumar A, Fu C C, Chiu J M, Chang H H, Wen K L and Cheng C H 2013 Temporal variation of soil gas compositions for earthquake surveillance in Taiwan; Radiat. Meas. 50 154-169 (10.1016/j.radmeas.2012.11.007).

Yang T F, Walia V, Chyi L L, Fu C C, Chen C H, Liu T K, Song S R, Lee C Y and Lee M 2005 Variations of soil radon and thoron concentrations in a fault zone and prospective earthquakes in SW Taiwan; Radiat. Meas. 40 496-502.

Yang T F, Wen H Y, Fu C C, Lee H F, Lan T F, Chen A T, Hong W L, Lin S J and Walia V 2011 Soil radon flux and concentrations in hydrothermal area of the Tatun Volcano Group, northern Taiwan; Geochem. J. 45 483-490. 